\title{
Development of chicks and predispersal behaviour of young in the Eagle Owl Bubo bubo
}

\author{
V. PENTERIANI, ${ }^{1 *}$ M. M. DELGAdO,${ }^{1}$ C. MAGGIO ${ }^{2}$ A. ARADIS ${ }^{3} \&$ F. SERGIO ${ }^{1}$ \\ ${ }^{1}$ Department of Applied Biology, Estación Biológica de Doñana, C.S.I.C., Avda. de María Luisa s/n., Pabellón del Perú, \\ Apdo 1056, 41013 Seville, Spain \\ ${ }^{2}$ Centre for Wildlife Assessment and Conservation, AMS Building, The University of Reading, Whiteknights, PO Box 228, \\ Reading RG6 6AJ, UK \\ ${ }^{3}$ Istituto Nazionale per la Fauna Selvatica, Via Ca'Fornacetta 9, 40064 Ozzano Emilia (Bologna), Italy
}

Little quantitative information on the development and behaviour of chicks and young is available for many species, despite the crucial importance of such data and the sensitivity of this stage in a bird's life. For Eagle Owls Bubo bubo, despite the large amount of scientific literature on this species, much basic information is lacking. This study provides a photographic and morphometric guide for age estimation of nestlings and fledglings, as well as data on the call behaviour of young, and patterns of movements during the post-fledging dependence period. The most remarkable event in chick development is the rapid increase in mass, and size gain, during the first 30 and 40-45 days, respectively. Because after this time morphometric differences become less evident, young-feather development is more useful for ageing. Patterns of chick call behaviour showed that the time spent calling increased with age and, from 110 days of age, chick vocalizations were usually uniformly distributed through the whole night and most synchronized at sunset and sunrise (the maximum recorded number of vocalizations per chick and per night was 1106 calls). During the post-fledging dependence period, radiotagged Owls moved widely, up to $1500 \mathrm{~m}$ from the nest after the age of 80-90 days. During such movements, the mean distance among siblings increased with age, from $168 \mathrm{~m}$ on average for juveniles less than 100 days old, to $489 \mathrm{~m}$ for those older than 100 days. Definitive dispersal started when young were about 150-160 days old. Information on chick call behaviour and movements is crucial for unbiased census and nest checking, as well as for the definition of young post-fledging areas. Knowledge of the latter is very important in terms of conservation and management (especially for those species that move largely around their nest before dispersal) owing to the high mortality that can occur during this period.

Information on the development and behaviour of nestlings and fledglings is scarce for most species. This is a cause for concern because of the crucial importance of such data for more sophisticated studies, and the sensitivity of this stage in a bird's life (e.g. Lack 1954, Bustamante \& Hiraldo 1989, Bustamante \& Negro 1994, Amar et al. 2000).

Accurate estimate of nestling age is important for (a) investigating several aspects of the life histories of individual species (e.g. Murphy 1981), (b) differentiating between different plumages (e.g. Hill 1987),

*Corresponding author.

Email: penteriani@ebd.csic.es (c) ageing museum specimens (McCollough 1989),

(d) scheduling ringing (e.g. Fyfe \& Olendorff 1976),

(e) assessing productivity (e.g. Steenhof 1987, Young

\& Kochert 1987) and (f) backdating hatching data (e.g. Sergio \& Bogliani 1999, Marchesi et al. 2002, Penteriani et al. 2002). With regard to hatching data, and as reported by Sergio (2003) for Black Kites Milvus migrans, backdating errors are negligible until some threshold is reached. Such thresholds, which are probably genus- and /or species-specific, are generally unknown, inaccurate or unpublished. In many species, poor nest accessibility, research on sensitive species and conservation concerns may oblige researchers to estimate nestling age from a distance, 
raising the need for an accurate knowledge of nestling feather and morphological change. Such a situation often applies to diurnal and nocturnal raptors. To our knowledge, accurate and complete descriptions and guides on the morphological changes that occur during nestling development have only been produced for the Prairie Falcon Falco mexicanus, Red-tailed Hawk Buteo jamaicensis, Ferruginous Hawk Buteo regalis and Goshawk Accipiter gentilis (Moritsch 1983a, 1983b, 1985, Boal 1994), whereas guides to the ageing of adults (or description of changes when passing from juvenile to adult plumage) are more common (Josephson 1980, Warkentin et al. 1992, Forsman 1999 and references therein, Clark 2000, Martínez et al. 2002, Hartley \& Mundy 2003).

Growth rates represent another fundamental aspect of avian life histories (Lack 1968). For example, correlations exist between the rate of nestling development and body weight (Ricklefs 1968), rate of nestling mortality (Ricklefs 1969), precocity of development (Ricklefs 1973), diet (Morton 1973) and adult foraging mode (O’Connor 1975). Moreover, growth rates can provide quantitative information for ageing and sexing of nestlings (Holcomb \& Twiest 1971, Hamel 1974).

The number of fledglings is typically reported in avian reproductive studies as a good estimate of breeding success. However, using fledging success alone to estimate annual breeding performance can lead to overestimates, and fail to identify an important stage of high mortality (e.g. Keedwell 2003 and references therein). In birds, the post-fledging dependence period (i.e. the period from fledging to dispersal, hereafter PFDP) represents a critical lifehistory stage (Weathers \& Sullivan 1989), as indicated by the high mortality rates that occur at this time (Lack 1954, Henny 1972, Sullivan 1989). For several species, the young continue to use a large portion of the parental home range in the PFDP (i.e. post-fledging area; Belthoff \& Ritchison 1989, Kenward et al. 1993, Kennedy et al. 1994, King \& Belthoff 2001), an aspect often overlooked because most attention is focused on the immediate surroundings of the nest-site. For these reasons, knowledge of juvenile behaviour during the PFDP and any clues allowing the detection of juveniles within the natal area (e.g. feature of vocal behaviour) could be useful tools for research.

The Eagle Owl Bubo bubo is widely distributed across Europe, Asia and North Africa and occurs in a variety of habitats (Penteriani 1996). Despite the large amount of scientific literature on this species, some basic information is lacking. Here, we provide: (1) a photographic and morphometric guide for estimating the age of young Eagle Owls, (2) data on nestling and fledgling call behaviour (together with sonagrams of different calls) and (3) information on patterns of movements by fledglings during the PFDP.

\section{METHODS}

\section{Study area}

This study was conducted from January to August 2003 in the Sierra Norte (Sierra Morena massif), $20 \mathrm{~km}$ north of Seville (southwestern Spain). The area comprises an artificial lake (Embalse del Gergal, 250 ha), two river valleys (Cala and Huelva rivers) and its surrounding hills, ranging between 60 and $200 \mathrm{~m}$ in altitude. The landscape is dominated by sparse woodlands composed of Holm Oaks Quercus ballota, Gall Oaks Quercus faginea, Stone Pine Pinus pinea, Olive Trees Olea europaea, Lentisk Pistacea lentiscus and small plantations of Eucalyptus Eucalyptus sideroxylon. In many areas, scrubland has replaced woodland. Most of the area is managed for game species (mainly Red-legged Partridges Alectoris rufa and European Rabbit Oryctolagus cuniculus).

\section{Development of the young}

The majority of nests were on the ground or on very accessible cliffs, a rather rare situation for Eagle Owls, allowing a precise recording of the chick's growth with minimum nest disturbance. We studied the morphological and morphometric development of 19 chicks from eight nests, from the first day after hatching (i.e. 1 day old) until they were 60 days old, after which it became difficult to find, approach or catch the young. In fact, especially for nests on the ground or on small cliffs, juveniles can leave the nest at c. 40-45 days of age and spend the day more than $500 \mathrm{~m}$ from the nest. Moreover, from this stage onwards, the visible differences in plumage etc. become very subtle, making exact age-estimation from a distance quite difficult.

We visited all the nests every 5 days, taking both photographs of the young and morphometric measurements of the body parts most useful in describing patterns of growth in this species (Delgado \& Penteriani in press): length of forearm, bill, tarsus, and wing, and body weight. Measurements were made with digital calipers and nestling weight was estimated to the nearest $10 \mathrm{~g}$ with 1 - and 2.5-kg Pesola scales, 
depending on the growth stage of the individuals. The terminology for body parts reported here follows Boal (1994). The growth rate $(K)$ and curve were calculated following Ricklefs (1967, 1973), the latter being fitted by the von Bertalanffy equation. Moreover, to provide a better comparison of Eagle Owl growth patterns with those of other owl species, we calculated (see Ricklefs 1968 for more details): (1) the ratio $(R)$ between the average young weight and the asymptote of the growth curve, and (2) an inverse measure of growth rate $\left(t_{10-90}\right)$, which represents the time required for growth between 10 and $90 \%$ of the asymptote. This time interval represents a practical index because it varies directly with temporal features related to growth (such as the duration of incubation and nestling periods), allowing comparisons between species (Ricklefs 1967). We did not consider the possible influence of sex on the growth patterns because of the small sample size.

\section{Call behaviour}

To study the vocal behaviour of the young during the dependence period, we carried out quantitative listening sessions similar to Penteriani et al. (2000) and Penteriani (2001, 2002, 2003). We systematically listened to eight fledged young (from four different nests) from the age of 70 days, when their typical chwätch call (Mikkola 1983) starts to be detected easily, to the start of dispersion (c. 150-160 days old, M.M.D. and V.P. unpubl. data). This call is also audible from about the 40th day of life, but at this time the call is only detectable at close range and the frequency during the night is low. As changes in the breeding cycle might interfere with call data, each site was systematically checked throughout the breeding period. Finally, to be sure that after fledging the eight individuals were in the vicinity of their nest during the listening sessions, we radiotagged them (see below) and recorded their position 5-8 times during each nocturnal session of call listening (i.e. at sunset, at sunrise and in the middle of the night). For the listening sessions, we divided the period in which the young stay in the parents' territory into five blocks of 20 days, i.e. when the young were 70,90 , 110, 130 and 150 days old.

Within each period of 20 days we made one night listening session. Listening sessions started $1 \mathrm{~h}$ before sunset and ended $1 \mathrm{~h}$ after sunrise. For the night within each 20-day interval, we (1) calculated the duration of the night (in minutes), subdivided it into a number of time-slots (of equal length) equal to the number of measured chicks $(n=8)$ and (2) assigned each slot to a chick on a rotational basis. During this period (April to August), we recorded the following data: (1) time when a call began; (2) duration of the vocal bout (a series of single chwätch, determined by a stopwatch, hereafter termed bout duration) - we defined the end of a bout as the last call heard at least $60 \mathrm{~s}$ before the next call (i.e. 1 min of silence between calls was regarded as a dividing unit of time); (3) number of calls within each series (a value of $1 \mathrm{~s}$ was arbitrarily ascribed to one isolated call); and (4) time of the first and last call of the night.

During the listening sessions, we also recorded the chicks' calls using a Sony digital audiotape recorder (TCD-D100) and a Sennheiser directional microphone (condenser microphone ME 67 plus powering module K6). The analog recordings were digitized at a $22.05 \mathrm{kHz}$ sampling rate using the sound recorder program of Microsoft Windows 2000 on a PC platform. We prepared digital spectrographs with Avisoft-SASLab Pro v.3.3 with an effective bandwidth of $111 \mathrm{~Hz}$ and a 256-point fast Fourier transform (FFT) size.

\section{Movements during the PFDP}

Young Eagle Owls were fitted with adjustable 30-g harness mounted backpacks (Biotrack Ltd, Wareham, UK) at the age of 35-50 days. Because at this time the young are still growing, backpacks were adjusted in such a way that the Teflon ribbon could expand and allow for the increased body size. Individual animals were located using three-element hand-held Yagi-antennas with Stabo (XR-100) portable receivers. On nights other than those of the listening sessions, we tried to obtain as many fixes as possible of each juvenile uniformly distributed through the whole night. After transmitter attachment, the birds were located every 3-5 days, and locations obtained after the birds were independent of the parents were not included in the current analyses. Because fewer than 20 high-quality fixes were obtained for the majority of juveniles, we did not estimate home range size for fledglings (Kennedy et al. 1994). We considered the start of natal dispersal to be when: (1) a juvenile spent more than three consecutive days at least $2 \mathrm{~km}$ from the nest (i.e. out of the adults' home range, based on telemetry data, M.M.D. and V.P. unpubl. results) and (2) successive movements led it increasingly away from the nest, following Marquiss and Newton (1981), Kenward 
et al. (1993) and Kennedy et al. (1994). All means of movement patterns are reported \pm 1 sd.

\section{RESULTS}

\section{Development of chicks and fledglings}

The most remarkable aspect of the development of young Eagle Owls is the rapid increase in weight, and size gain, during the first 30, and 40-45 days, respectively (Table 1 and Fig. 1). After these two time thresholds, there is a notable reduction in the rate of mass gain. Consequently, morphometric differences among the young in the successive 5-day periods are not as evident as in the initial phase. Calculated growth parameters are given in Table 2, as well as the growth parameters of other owl species for which such information was available in the

Table 1. Weight gain and morphometric development (mean \pm sd (range)) for forearm, bill, tarsus and wing of young Eagle Owls from 5 to 60 days old.

\begin{tabular}{lccccc}
\hline Age (days) & Forearm $(\mathrm{mm})$ & Bill $(\mathrm{mm})$ & Tarsus $(\mathrm{mm})$ & Wing $(\mathrm{cm})$ & Weight $(\mathrm{g})$ \\
\hline 5 & $35.07 \pm 3.23$ & $13.00 \pm 0.40$ & $32.45 \pm 5.20$ & $74.25 \pm 13.12$ & $131.25 \pm 45.89$ \\
& $(31.81-39.41)$ & $(12.57-13.48)$ & $(26.06-38.37)$ & $(62.00-90.00)$ & $(80.00-170.00)$ \\
10 & $48.22 \pm 3.50$ & $17.27 \pm 3.11$ & $40.91 \pm 2.18$ & $100.00 \pm 14.14$ & $285.00 \pm 21.21$ \\
& $(45.78-50.66)$ & $(15.07-18.47)$ & $(39.37-42.45)$ & $(90.00-110.00)$ & $(270.00-300.00)$ \\
15 & $67.14 \pm 4.02$ & $18.42 \pm 0.47$ & $54.10 \pm 2.65$ & $163.33 \pm 5.77$ & $530.00 \pm 75.50$ \\
& $(62.58-70.15)$ & $(18.13-18.96)$ & $(52.43-57.16)$ & $(160.00-170.00)$ & $(450.00-600.00)$ \\
20 & $90.91 \pm 1.86$ & $21.40 \pm 0.21$ & $68.83 \pm 8.15$ & $226.67 \pm 20.82$ & $810.00 \pm 36.06$ \\
& $(88.80-92.31)$ & $(21.20-21.62)$ & $(60.42-72.00)$ & $(210.00-250.00)$ & $(780.00-850.00)$ \\
25 & $111.95 \pm 8.48$ & $22.84 \pm 0.44$ & $69.32 \pm 3.05$ & $275.00 \pm 21.79$ & $1003.33 \pm 205.51$ \\
& $(106.37-121.71)$ & $(22.52-23.35)$ & $(66.41-72.49)$ & $(260.00-300.00)$ & $(870.00-1240.00)$ \\
30 & $126.04 \pm 6.56$ & $24.68 \pm 0.21$ & $80.55 \pm 4.18$ & $355.00 \pm 8.66$ & $1166.67 \pm 125.83$ \\
& $(121.55-133.56)$ & $(24.49-24.90)$ & $(75.78-83.57)$ & $(350.00-365.00)$ & $(1050.00-1300.00)$ \\
35 & $164.00 \pm 10.39$ & $24.87 \pm 1.92$ & $81.47 \pm 5.22$ & $396.33 \pm 35.64$ & $1323.33 \pm 144.68$ \\
& $(152.00-170.00)$ & $(22.65-25.04)$ & $(77.81-87.45)$ & $(359.00-430.00)$ & $(1230.00-1490.00)$ \\
40 & $177.00 \pm 5.29$ & $27.58 \pm 1.73$ & $94.38 \pm 0.09$ & $482.63 \pm 26.29$ & $1375.00 \pm 64.55$ \\
& $(170.00-182.10)$ & $(26.16-29.99)$ & $(94.31-94.44)$ & $(460.00-520.00)$ & $(1300.00-1450.00)$ \\
45 & $177.50 \pm 3.54$ & $27.43 \pm 0.33$ & $94.76 \pm 1.62$ & $565.00 \pm 21.21$ & $1400.00 \pm 424.26$ \\
& $(175.10-180.00)$ & $(27.20-27.66)$ & $(93.13-96.72)$ & $(550.00-580.00)$ & $(1100.00-1600.00)$ \\
50 & $185.00 \pm 7.07$ & $27.65 \pm 1.24$ & $99.46 \pm 0.50$ & $573.33 \pm 23.09$ & $1533.33 \pm 152.75$ \\
& $(180.00-191.15)$ & $(26.67-28.52)$ & $(97.46-99.95)$ & $(560.00-600.00)$ & $(1400.00-1700.00)$ \\
55 & $188.67 \pm 9.29$ & $29.10 \pm 1.71$ & $100.62 \pm 7.05$ & $575.00 \pm 7.07$ & $1590.00 \pm 141.42$ \\
& $(185.20-192.05)$ & $(27.29-30.69)$ & $(98.31-108.23)$ & $(570.00-580.00)$ & $(1500.00-1800.00)$ \\
60 & $200.00 \pm 10.04$ & $31.05 \pm 0.89$ & $105.26 \pm 5.35$ & $585.00 \pm 21.22$ & $1775.00 \pm 176.78$ \\
& $(190.00-207.57)$ & $(30.42-31.68)$ & $(101.49-109.06)$ & $(575.00-600.00)$ & $(1600-1900.00)$ \\
& & & & &
\end{tabular}

Table 2. Growth and life history parameters of owl species (for which growth rate is available in literature).

\begin{tabular}{|c|c|c|c|c|c|c|c|c|}
\hline \multirow[b]{2}{*}{ Species $(n)$} & \multirow{2}{*}{$\begin{array}{l}\text { Age of 1st } \\
\text { flight } \\
\text { (days) }\end{array}$} & \multirow{2}{*}{$\begin{array}{l}\text { Clutch } \\
\text { size }\end{array}$} & \multirow{2}{*}{$\begin{array}{l}\text { Adult } \\
\text { weight } \\
\text { (g) }\end{array}$} & \multirow{2}{*}{$\begin{array}{l}\text { Ratio } \\
(R)\end{array}$} & \multicolumn{2}{|c|}{ Growth rate } & \multirow[b]{2}{*}{ Locality } & \multirow[b]{2}{*}{ Source } \\
\hline & & & & & $(K)$ & $\left(t_{10-90}\right)$ & & \\
\hline $\begin{array}{l}\text { Bubo virginianus } \\
\text { (2) }\end{array}$ & $63-70$ & $2-3$ & 1175 & 1.02 & $0.094^{a}$ & 32.9 & $\begin{array}{l}\text { Kansas } \\
\text { (USA) }\end{array}$ & Hoffmeister \& Setzer (1947) \\
\hline $\begin{array}{l}\text { Nyctea scandiaca } \\
\text { (unknown) }\end{array}$ & approx 50 & $7-9$ & 1922 & 0.88 & $0.101^{a}$ & 30.7 & $\begin{array}{l}\text { Baffin Is. } \\
\text { (Canada) }\end{array}$ & Watson (1957) \\
\hline $\begin{array}{l}\text { Otus asio } \\
\text { (4) }\end{array}$ & approx 30 & $3-5$ & 150 & 0.80 & 0.264 & 16.7 & $\begin{array}{l}\text { California } \\
\text { (USA) }\end{array}$ & Sumner (1928) \\
\hline $\begin{array}{l}\text { Tyto alba } \\
\text { (10) }\end{array}$ & 67 & $2-7$ & 408 & 1.40 & 0.152 & 29.0 & $\begin{array}{l}\text { California } \\
\text { (USA) }\end{array}$ & $\begin{array}{l}\text { Sumner (1929) } \\
\text { Pickwell (1948) } \\
\text { Howell (1964) }\end{array}$ \\
\hline $\begin{array}{l}\text { Bubo bubo } \\
\text { (19) }\end{array}$ & approx $>50$ & $2-5$ & 1900 & 1.42 & $0.044^{\mathrm{b}}$ & 48.76 & $\begin{array}{l}\text { Andalusia } \\
\text { (Spain) }\end{array}$ & this study \\
\hline
\end{tabular}

Equation used to fit the growth curve: ${ }^{a}$ Gompertz; ${ }^{b}$ von Bertalanffy; if not stated = logistic. 

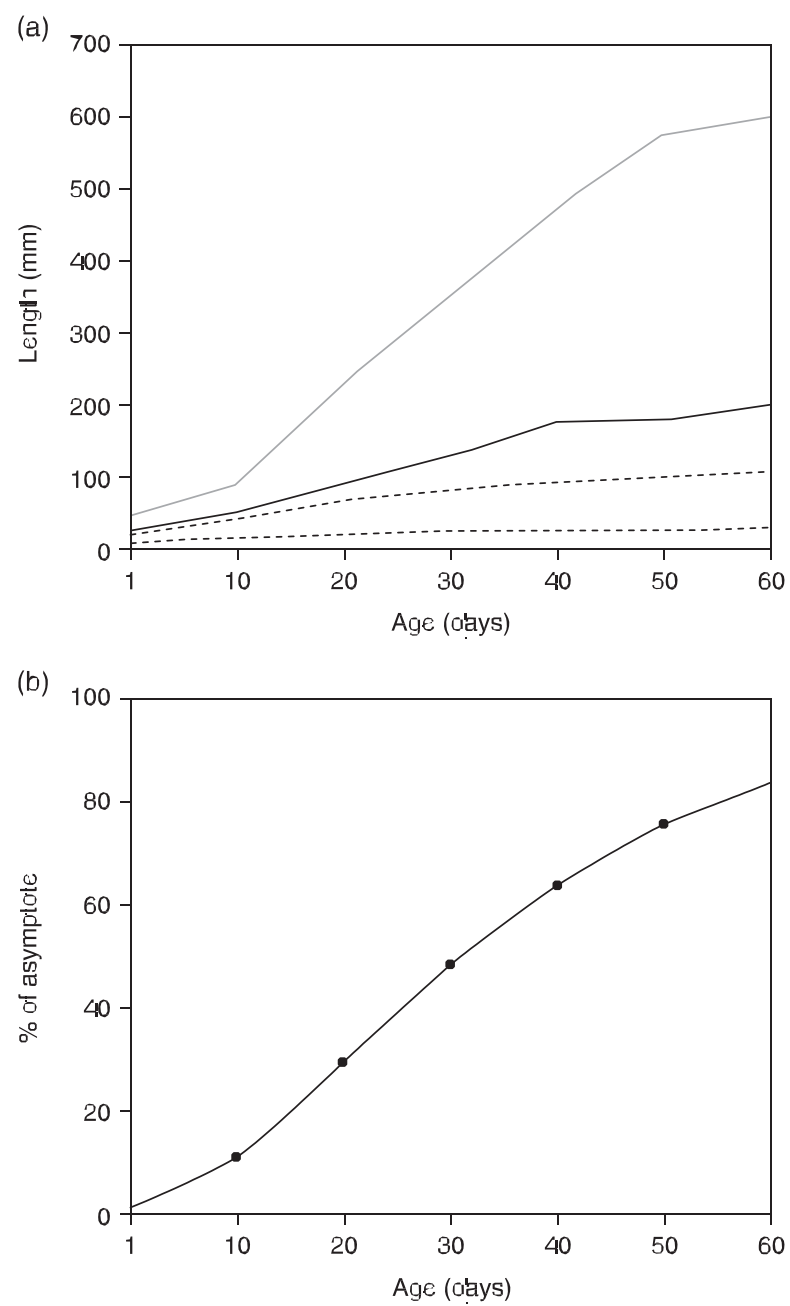

Figure 1. (a) Starting from c. 40 days old, young Eagle Owls $(n=19)$ show a general decline in the rate of morphometric development in (from top to bottom): mean length of wing (grey line), forearm (black solid line), tarsus (black broken line) and bill (black dotted line). That is, after the first 40 days of life, morphometry could give inaccurate estimates of age. (b) A similar trend shows the mean weight increase, as illustrated by the growth curve (calculated from the von Bertalanffy equation), expressed as the percentage of the asymptote. This type of growth curve is typical of species whose nestling weights level off below adult weight and growth is completed after the young leave the nest.

literature. The $K$ value was 0.044 , corresponding to a weight increase of $0.025 \mathrm{~kg} /$ day. Time interval for growth from 10 to $90 \%$ of the asymptote was 48.76 days, a relatively large value compared with other Strigiformes (Table 2).

More evident and useful for ageing the young are the differences in morphology (see Figs $2-12$, in which all the most important details for correctly ageing young Eagle Owls are described). Nestlings

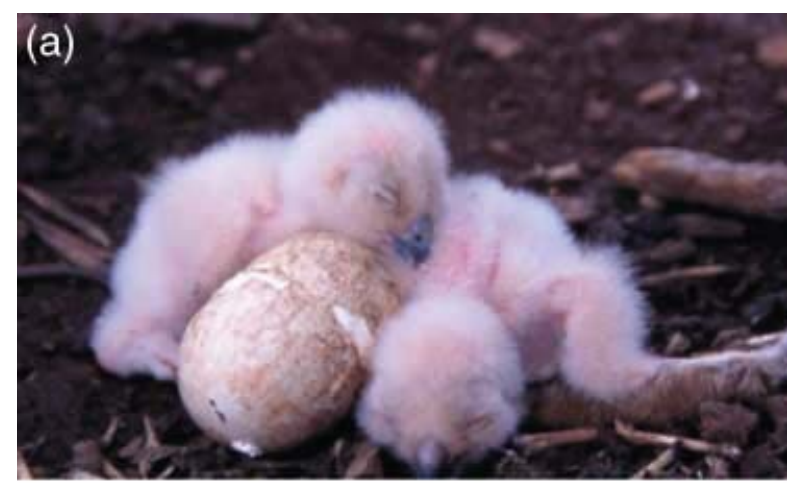

(b)

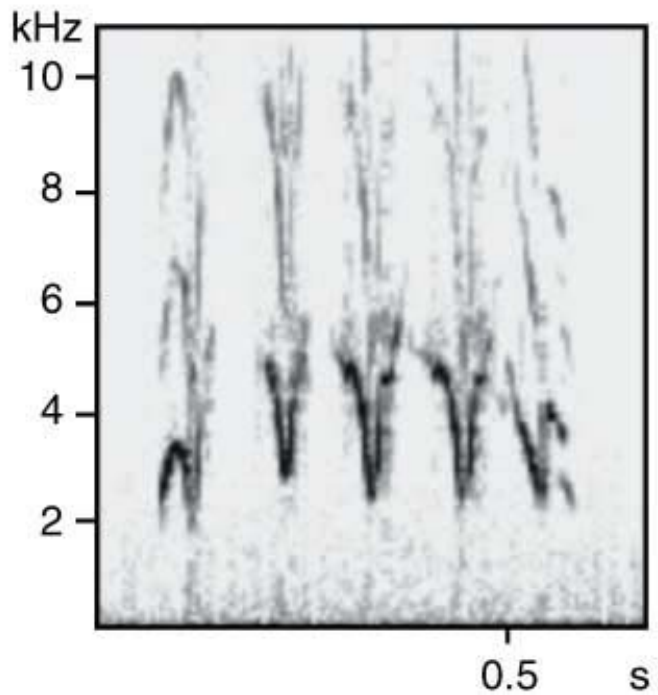

Figure 2. Eagle Owl chick at 1-3 days post-hatching. Nestlings are covered in a whitish first down and their eyes are still closed. Some parts of the body are still naked (e.g. shoulders, belly), resulting in some light pink patches. The eyes start to open at 4 days and are completely open by the age of 6-7 days. At this time, the eyes have a grey-blue pupil and a dark yellow iris. Nestlings lie prostrate, the body in contact with the substrate, they have pink toes and tarsus with light grey claws. They may give an acute and plaintive call.

remained totally white until 10-12 days (Figs 2 \& 3 ), when they started to show a barred appearance and a greyish-beige uniform pattern (Figs 4-7). Starting from c. 30 days, rapid and noticeable feathering (i.e. remiges) occurs, as well as the development of ear tufts and a well-defined facial mask (Figs 7-9). Scapulars and coverts become evident at 45 days (Figs 10-12).

Adult behaviour changes with nestling and fledging age. Generally, during the first month of the nestlings' lives, females spend most of the day in the nest, whereas territorial defence and hunting are left to the males. Females start to move to a different diurnal roost when the young are 30-40 days old. During this period, 


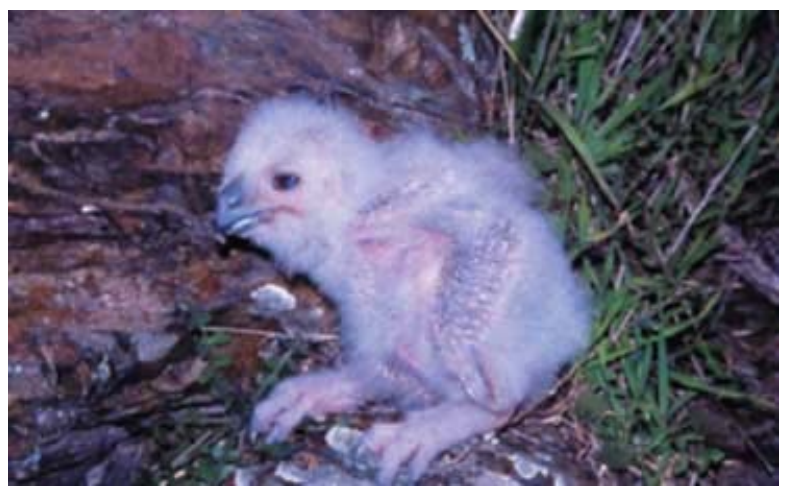

Figure 3. Eagle Owl chick at 10 days post-hatching. Nestlings are still covered in white down. Clearly visible are sheathings along the shoulders, in correspondence of the future rectrices (close to the rump), scapulars and remiges, as well as in the upper parts of the tarsus. Two parallel shaft lines mark the thorax. The belly starts to be covered by down.

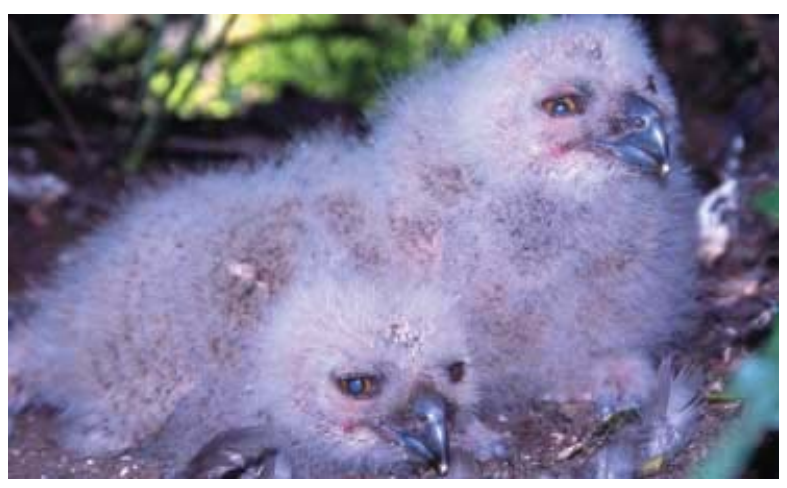

Figure 4. Eagle Owl chicks at 15 days post-hatching. The white colour of down tends to be more and more grey-beige, and the appearance of a second down gives the birds a 'streaked' aspect (especially on the wings, shoulders and rump). The down is now abundant around the body and has a woolly appearance. The development of pin feathers starts to be apparent, and primaries and coverts are of c. 7 and $13 \mathrm{~mm}$, respectively, outside the pin feather sheaths. Eyes are more protruded and a yellow-orange iris appears around the grey-blue pupil. Covering of the belly by down is still incomplete. Evident in the picture is the still present egg tooth and the initial white patch around the bill. Nestlings are now able to take an aggressive posture, opening the wings and snapping their bills, even if they are not yet very stable on their feet. We strongly recommend not checking nests before this age.

diurnal roosts of both parents are close to the nest (which is always visible from the roosts), although the male often spends the day further from the nestlings/fledglings than does the female. After fledging, the female may also contribute to territorial defence against conspecific intruders. Furthermore, if the young are able to leave the nest when $40-45$ days old but

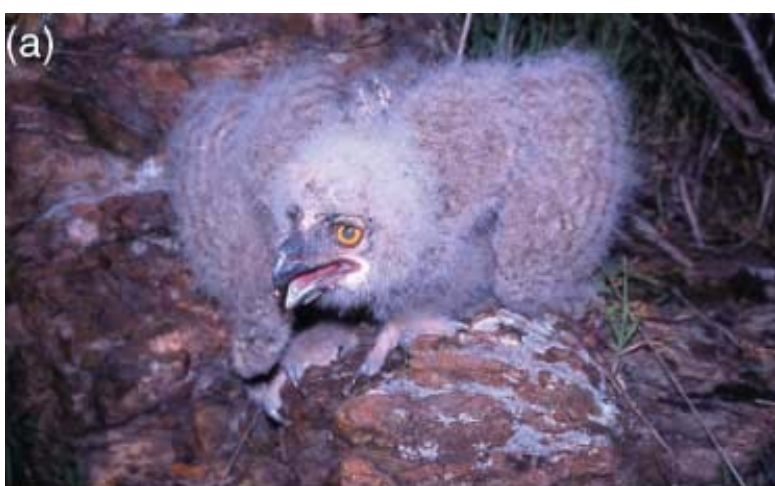

(b) $\mathrm{kHz}$

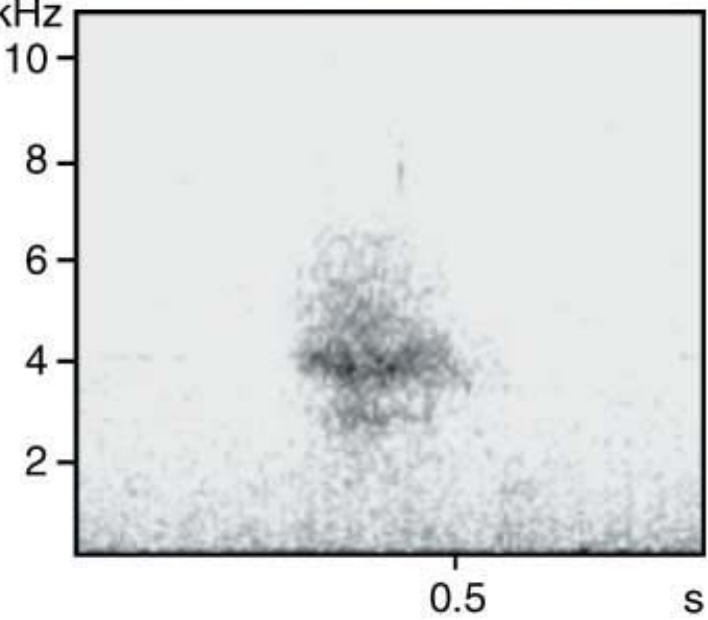

Figure 5. Eagle Owl chick at 20 days post-hatching. The streaked aspect of nestlings is more and more evident, with the body entirely covered by dense down except on the belly, still incompletely feathered in the middle. The eruption of remiges from pin sheaths becomes more evident, especially for secondaries. Pin feather development between nape and back starts. Bill colour is darker and vibrissa appear surrounding. The white patch around the bill now markedly contrasts the down around it, even if its development is limited to a small patch on the lower extremity of the bill. At this stage the nestlings start to emit their typical chwätch call. The yellow-orange iris is larger and the pupil more and more blue (the grey texture is disappearing). Feet and claws start to resemble those of an adult.

still unable to fly, 'fledging' seems to be directly correlated with nest-site morphology: the more the nest is on high and vertical cliffs (where fledging needs to be the first real flight), the later fledging takes place.

\section{Call behaviour}

The total number of calls per night per young ranged from 318 (at 70 days of age) to 1106 (150 days; see also Table 3). A positive relationship between the duration of call bouts and the number of calls per 


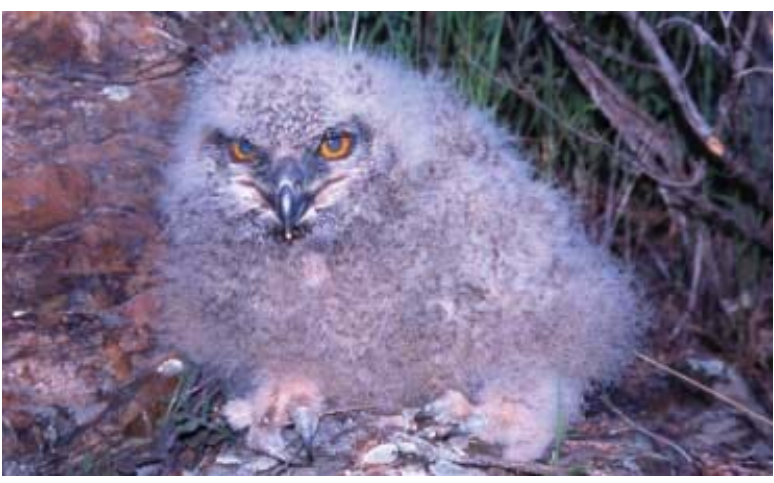

Figure 6. Eagle Owl chick at 25 days post-hatching. The white patch around the bill is more evident and the vibrissa are more abundant around the bill. On the crown, future ear tufts start to develop, although at this stage they are only made of down. The egg tooth disappears at this stage of nestling development. The general appearance of the young is darker, due to the more visible streaks. The down development on the belly is now complete. The black mask around the eyes appears. Pin feather development of the remiges, especially primaries and coverts, is now clear. Rectrice sheathings also appear.

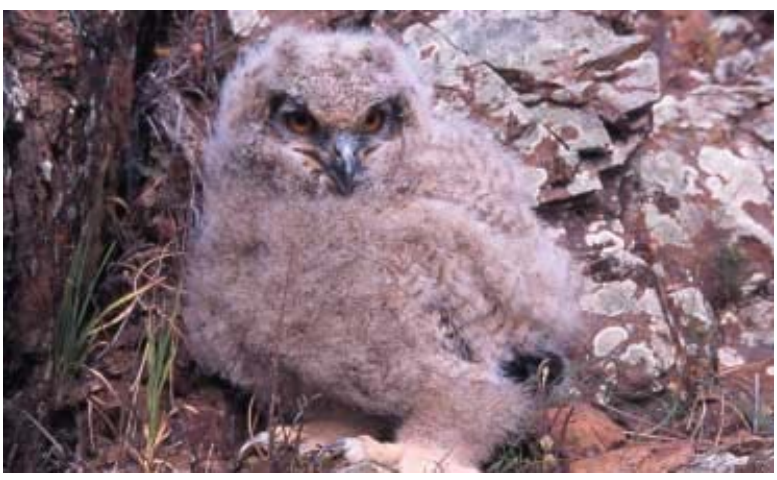

Figure 7. Eagle Owl chick at 30 days post-hatching. The general appearance is quite similar to the previous stage, but with all the above-cited morphological characteristics more developed. That is, more defined black and white patches on the facial mask, more prominent ear tufts and longer pin feathers (largest pin feathers are c. 8-9 cm, sheathing included). Dark brown patches on the feet have disappeared and they are now of a homogeneous cream-beige colour. At this stage, chick calls are difficult to discern from more than c. $300 \mathrm{~m}$ and females start to roost away from the nest.

bout was observed $\left(r_{\mathrm{s}}=0.90, P=0.037\right.$, Spearman rank). The duration of call bouts $\left(r_{\mathrm{s}}=0.89, P=0.041\right)$ and number of calls per bout $\left(r_{\mathrm{s}}=0.89, P=0.044\right)$ were positively correlated with age of juveniles (Fig. 13).

The duration of call bouts throughout the night differed significantly among the five age-classes $\left(\mathrm{X}^{2}=\right.$ $14.43, d f=4, P=0.006$, Friedman test). Young vocal

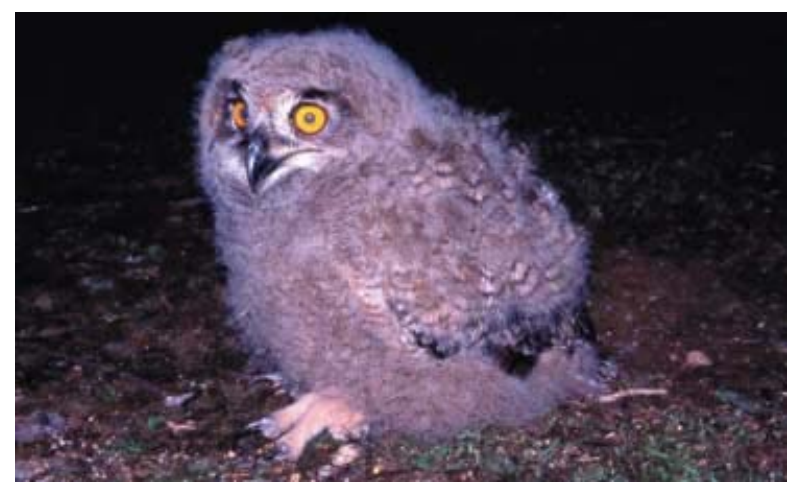

Figure 8. Eagle Owl chick at 35 days post-hatching. Changes between 30 and 35 days are pronounced, especially in the facial mask and wings. White contours around the bill and eyes are well marked, as well as the black spot on the upper part of the eyes. Ear tufts are longer and stick out clearly from the crown. Remiges (now also secondaries) and rectrices continue their eruption from pin sheaths and begin to form a quite visible horizontal bar along the wings. At this stage nestlings can walk out of the nest and roost at several tens of metres from it. If disturbed, they can throw themselves from the nest and glide away at considerable distances.

behaviour showed two main patterns by age ( Fig. 14): first, between 70 and 110 days, calling is mainly concentrated near sunset and sunrise, juveniles staying quite silent during the middle of the night (especially from 70 to 90 days). Calling in the middle of the night starts to increase from 110 days, showing the highest rates when juveniles are 130 and 150 days old. Finally, the young showed quite a cyclical vocal activity during the night, characterized by four peaks of intense calling, two of them coinciding with $1 \mathrm{~h}$ after sunset and $1 \mathrm{~h}$ before sunrise (Fig. 14). Such a pattern is mainly evident among the oldest age-classes.

During the post-fledging period, the vocal activity of adults is lower than in the previous and following months (M.M.D. \& V.P. unpubl. data). In addition, if some periods of young begging coincided with adult calling, many offspring vocalizations occurred at different times than sunset and sunrise (when adult calls were mainly concentrated) when their parents were absent (Fig. 15), as detected by radiotracking of the adults (M.M.D. \& V.P. unpubl. data).

At later-age stages, the first and last calls were also closer to sunset and sunrise, respectively, than before (Fig. 16). In particular, during the last three age-classes, the first call occurred only between 9 and $22 \mathrm{~min}$ after sunset, whereas at 70 and 90 days it occurred 81 and 83 min after dusk, respectively. Concerning the cessation of calling, juveniles always gave their 


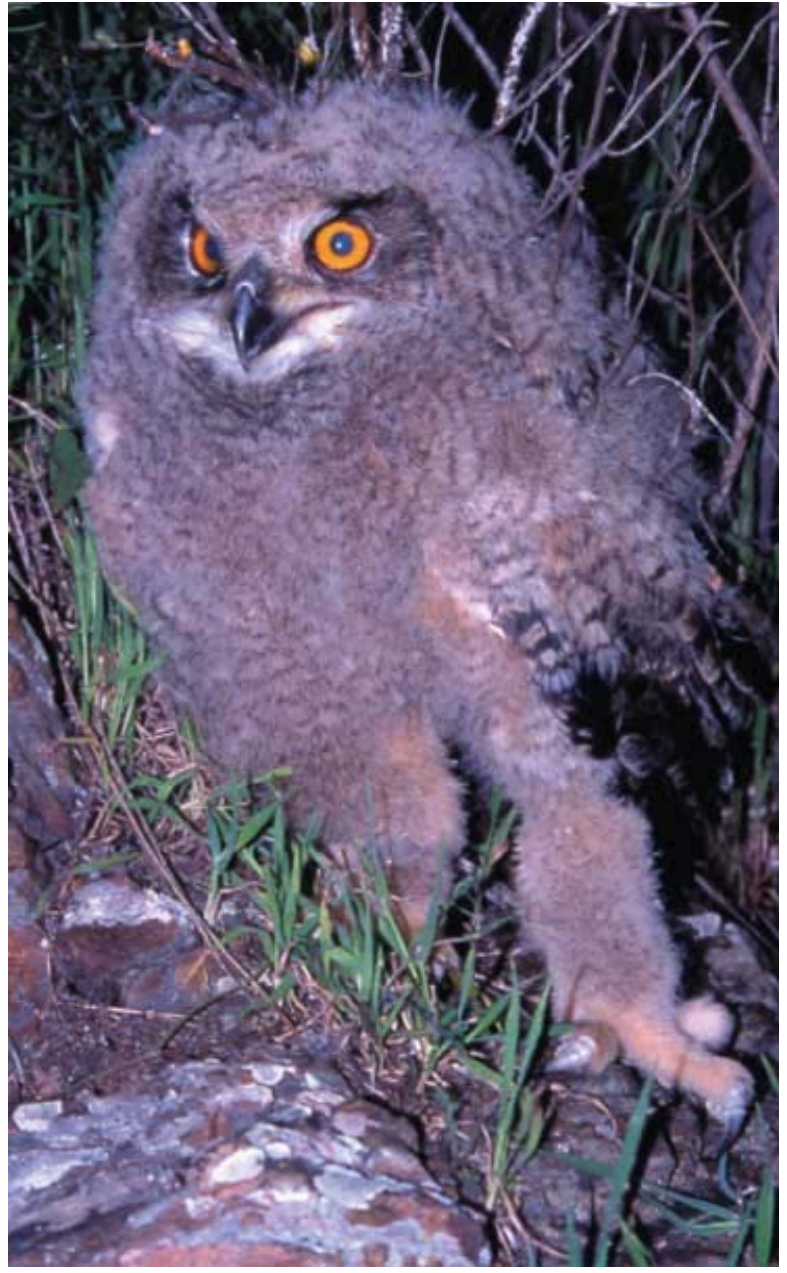

Figure 9. Eagle Owl fledgling at 40 days post-hatching. Primaries are about two-thirds full length and the emergence of tail feathers from sheaths is now pronounced. Feathers are starting to emerge on the nape and on the head, especially on the facial mask near the eyes.

last call before sunrise (range 9-47 min), except when they were 70 days old (i.e. 8 min after).

\section{Movements during the PFDP}

The eight Eagle Owl offspring that we studied for call behaviour ( $n=4$ nests) were also followed by radiotracking, allowing us to collect 168 location fixes from 45 (when fledglings start to move in the vicinity of the nest) to 150 days of age (when the first dispersal event was recorded). Moreover, because all the nestlings from a same nest were radiotagged, we were also able to evaluate the change in the mean distance among siblings. During the PFDP, the movements of the radiotagged owls showed that:

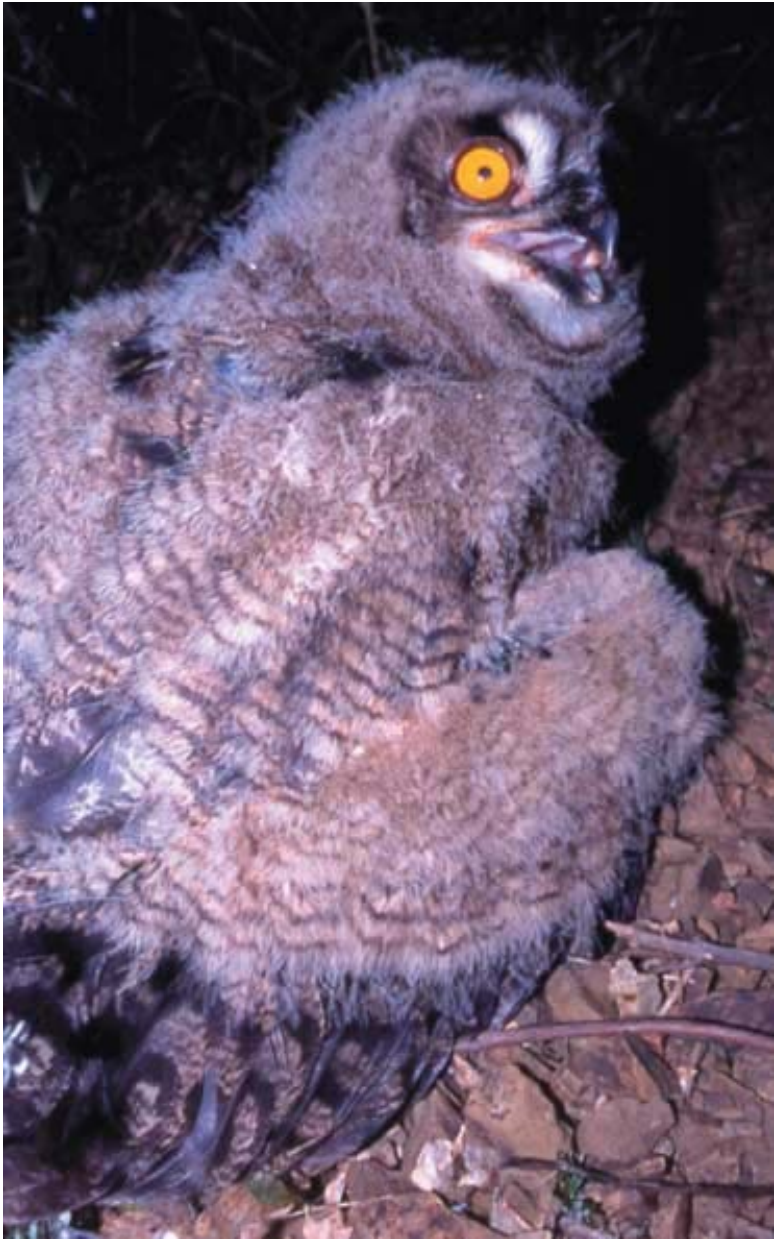

Figure 10. Eagle Owl fledgling at 45 days post-hatching. Primary remiges and rectrices (c. 8-9 $\mathrm{cm}$ of feather visible out of the sheath) are c. $80 \%$ and $40 \%$ of their definitive length, respectively. Secondaries are still encased in c. 7-8 cm sheathings. More and more nape, scapular and dorsal feathers are erupting from pin sheaths and begin to contrast markedly with the body down. Several feathers appear also in the upper part of the throat, at the base of the neck. Wing coverts begin to emerge. White and black patches on the facial mask are better defined.

(1) the mean distance from the nest was $504 \pm 266 \mathrm{~m}$ ( $n=168$ ); (2) the mean distance from the nest increased significantly with age $(t=-3.68, P=0.0001)$ : $492 \pm 307 \mathrm{~m}$ for juveniles $<100$ days old $(n=43)$ and $1040 \pm 88 \mathrm{~m}$ for juveniles $>100$ days old $(n=$ 125). However, from 85 days old, the absolute maximum distance between a juvenile and its nest could rise to $1500 \mathrm{~m}$; (3) the mean distance between siblings was $280 \pm 13 \mathrm{~m}(n=168)$, with maximum distances of 698 and $1318 \mathrm{~m}$ for juveniles of $<100$ and $>100$ days, respectively. The mean distance between siblings increased significantly with age 


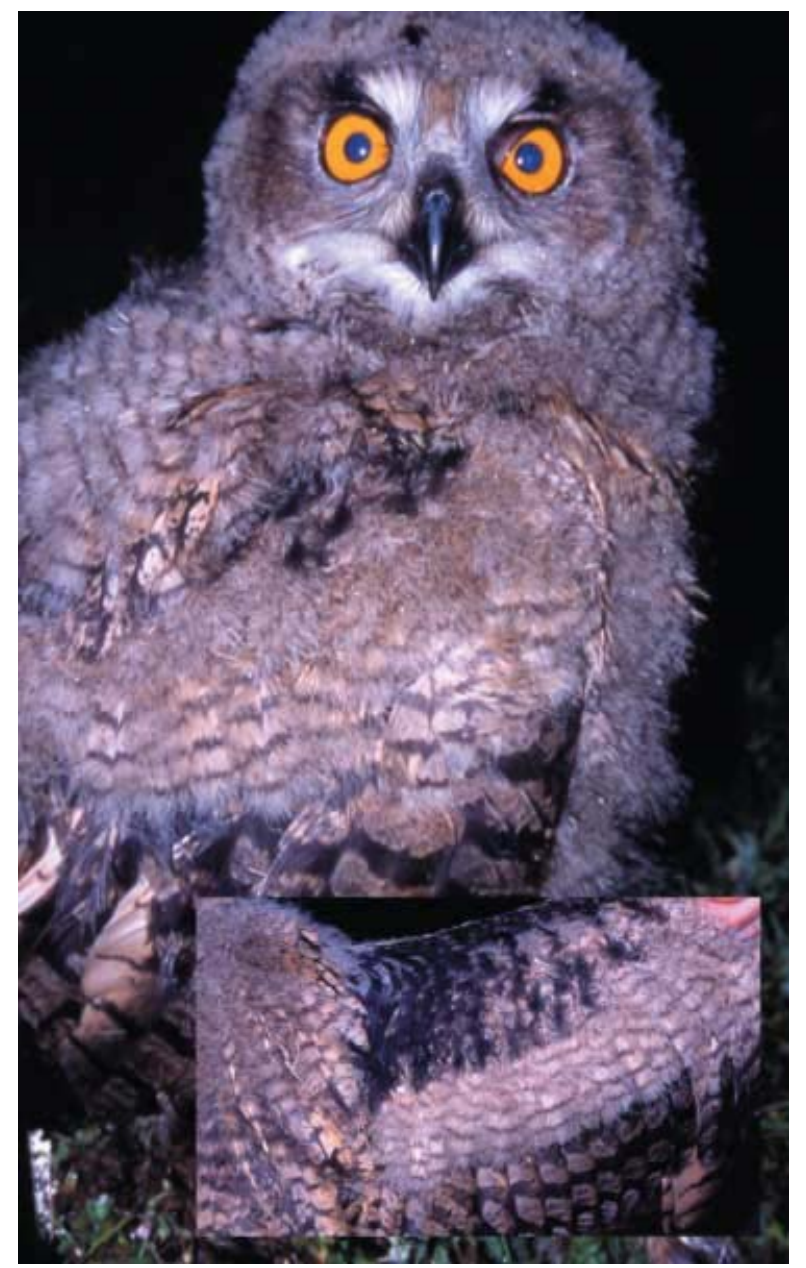

Figure 11. Eagle Owl fledgling at 50 days post-hatching. Feather sheaths of secondaries are now reduced to $c .4-6 \mathrm{~cm}$. Wing coverts continue their development and better contrast with the remaining downy areas. This represents a useful ageing element: at this stage, wings appear as separated in three clearly defined horizontal bands, i.e. a downy pale band between dark primaries and upper coverts (see detail of the open wing in inset photograph in lower right corner). Rectrices have reached about half their final length. A well-defined black line now separates the auricular area from the head.

$(t=-2.43, P=0.03)$, being $168 \pm 15 \mathrm{~m}$ for juveniles $<100$ days old $(n=43)$ and $489 \pm 81 \mathrm{~m}$ for those $>100$ days old $(n=125)$.

\section{DISCUSSION}

\section{Development of chicks and fledglings}

The general growth pattern in nestling raptors seems to be characterized by an early short period of slow weight gain and morphological development, fol-

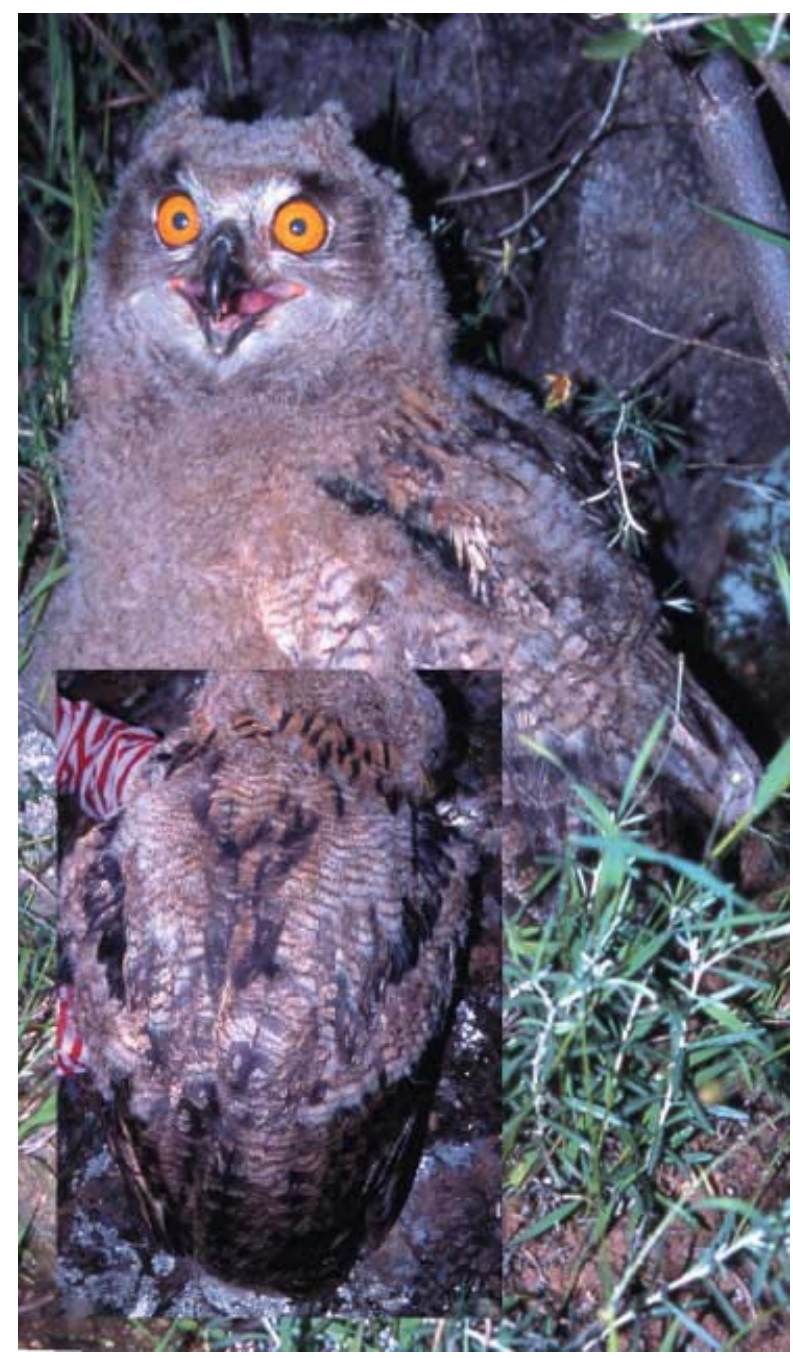

Figure 12. Eagle Owl fledgling at 60 days post-hatching. Morphological changes begin to be less evident at each stage and, consequently, ageing from the general feather pattern is more and more difficult. The most evident trait is the appearance of several well-developed feathers on the neck and the back (see detail in the lower left corner).

lowed by a period of rapid weight gain and general growth, and then a second stage of slower development (e.g. Moss 1979, Boal 1994). Young Eagle Owls fitted such a general pattern. The first phase was of about 10 days, during which growth and body development were slower than in the next 20 30 days (i.e. the second phase). A third 'plateau' phase in the growth could be observed from about the 30th (for the weight gain) and 40th (for the morphometry) day of life. During this third period, relying solely on morphometric data could produce critical errors in ageing the young. 
Table 3. Vocal behaviour (mean \pm sd (range)) of juvenile Eagle Owls from 70 to 150 days. The longest bouts and the largest numbers of calls correspond to the youngest age-class (70 days old), when calling activity is shortest and concentrated close to sunset and sunrise (see also Fig. 14). Time intervals are calculated between two neighbouring bouts, for both the entire night (max. time interval) and per hourly block (min. time interval).

\begin{tabular}{lccccc}
\hline & \multicolumn{5}{c}{ Age (days) } \\
\cline { 2 - 6 } Vocal features & \multicolumn{1}{c}{70} & 90 & 110 & 130 & 150 \\
\hline Bout duration (s) & $232.90 \pm 374.15$ & $126.08 \pm 254.97$ & $107.88 \pm 123.42$ & $126.85 \pm 263.11$ & $170.56 \pm 240.94$ \\
& $(1-1208)$ & $(1-1190)$ & $(1-372)$ & $(1-1780)$ & $(1-1072)$ \\
Calls per bout & $31.80 \pm 50.30$ & $13.83 \pm 20.57$ & $15.24 \pm 19.30$ & $11.87 \pm 20.55$ & $16.76 \pm 22.46$ \\
& $(1-164)$ & $(1-75)$ & $(1-64)$ & $(1-131)$ & $(1-94)$ \\
Max time interval (min) & $64.24 \pm 120.26$ & $20.16 \pm 49.03$ & $22.22 \pm 51.48$ & $9.38 \pm 16.08$ & $7.18 \pm 15.60$ \\
Min time interval (min) & $(1-370)$ & $(1-225)$ & $(1-237)$ & $(1-85)$ & $(1-78)$ \\
& $5.69 \pm 7.33$ & $4.68 \pm 4.25$ & $8.34 \pm 10.89$ & $6.75 \pm 9.28$ & $4.92 \pm 9.60$ \\
& $(1-20)$ & $(1-15)$ & $(1-48)$ & $(1-55)$ & $(1-59)$ \\
\hline
\end{tabular}

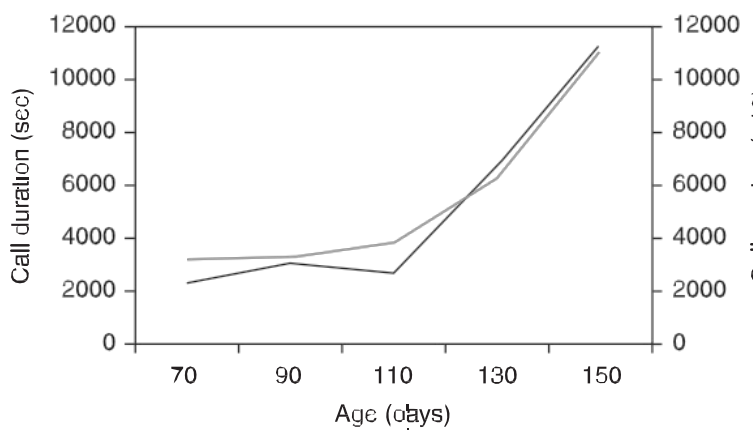

Figure 13. Vocalizations (per night) of juvenile Eagle Owls (black line = duration; grey line = call number) increase by age during the post-fledging dependence period.

The growth slowdown also corresponds to slow changes in morphological development. However, plumage characteristics become more useful and reliable for ageing at this stage. In fact, several plumage features (e.g. feathers appearing on the upper part of the throat and at the base of the neck, emergence of wing coverts, better definition of white and black patches on the facial masks, three horizontal bands of feathers on the wing; see Figs 9-12) may allow young Eagle Owls to be aged reliably until they are 60 days old. Finally, the modifications of the plumage are consistent among young, i.e. the pattern of feather growth was the same among all young of the same age.

The growth rate of Eagle Owls, as in the other owl species represented in Table 2, is typical of altricial species characterized by a slow growth and a long nestling period. In fact, all these species nest in secure and well-protected sites, allowing the young to remain in the nest longer than those that are

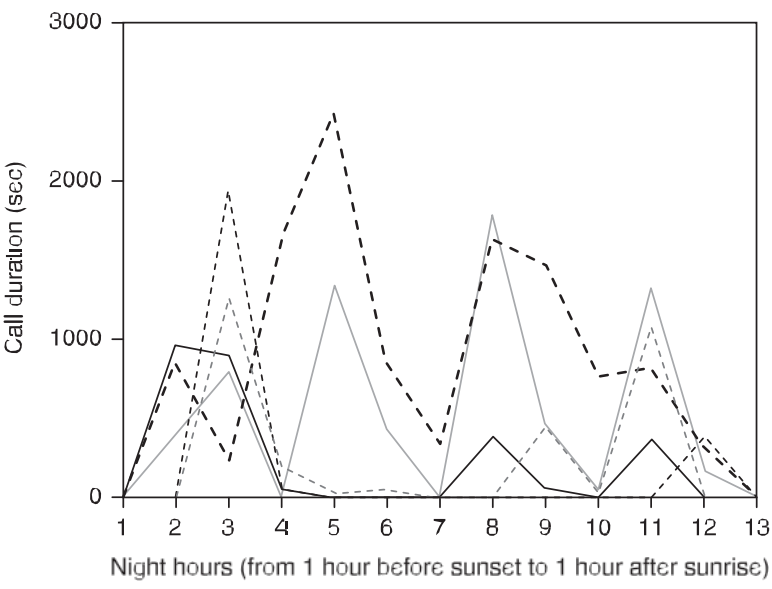

Figure 14. Call behaviour of juvenile Eagle Owls shows two different patterns by age (dotted line $=70$ days; broken line $=$ 90 days; black line $=110$ days; grey line $=130$ days; dotted bold line $=150$ days): between 70 and 110 days young calls are close to sunset and sunrise, whereas later in the development main vocalizations occur during the middle of the night. Four main peaks of vocal activity characterize the young call behaviour: at $1 \mathrm{~h}$ after sunset, $1 \mathrm{~h}$ before sunrise and at the 5th and 8th hours of the night. The $x$-axis represents night duration from $1 \mathrm{~h}$ before sunset (1) to $1 \mathrm{~h}$ after sunrise (13).

exposed to predators and inclement weather (Ricklefs 1968). It is interesting to note that the growth rate of Eagle Owls is the lowest among those owl species for which growth data are available, although it is similar to that of the Great Horned Owl Bubo virginianus, the North American geographical and ecological counterpart of the Eurasian Eagle Owl. Finally, although the clutch sizes of raptors and large passerines generally show a positive correlation with growth rate, Eagle Owls (as in Barn Owls Tyto alba 

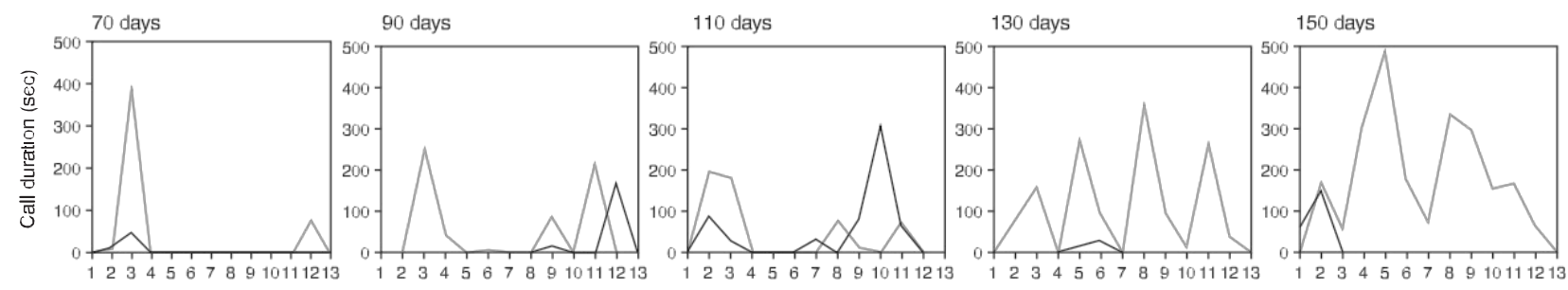

Night hours (from 1 hour before sunset to 1 hour after sunrise)

Figure 15. Temporal distribution of young (grey line) vs. adult (black line) vocal activity during the night. Even if there is a temporal correspondence between adult calling and young begging, the vocalizations of the latter two also occurred on 1-h periods different from sunset and sunrise and in the absence of their parents.
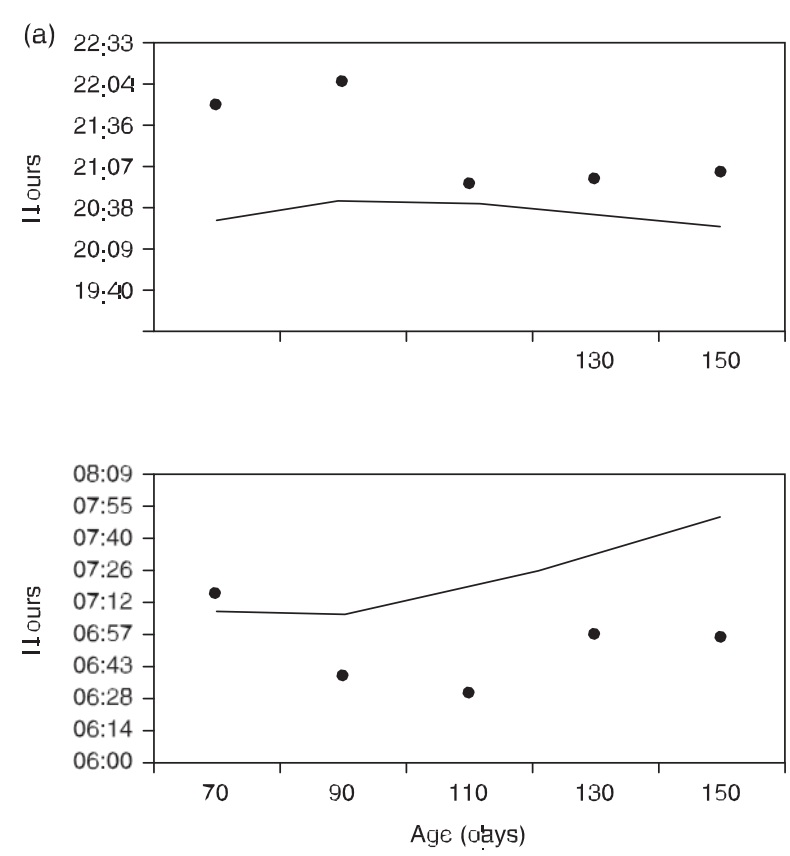

Figure 16. With increasing age of juvenile Eagle Owls, first call (a) is closer to sunset and last call is always before sunrise (b). Calls are represented by black spots. Solid line indicates real times of sunrise and sunset at the study area.

and Snowy Owls Nyctea scandiaca) have large clutches, and these are not associated with high growth rates.

There may be several reasons for a value of $R$ above 1, i.e. a nestling weight above that of the adults. However, such values are typical of species characterized by long nestling periods and young that are able to feed themselves after fledging (Ricklefs 1968).

\section{Call behaviour}

Patterns of young call behaviour showed that: (1) the duration of bouts and number of chwätch per night increased with age, especially from 110 days of life, even if the longest bouts and greatest number of calls per bout were recorded when the young were 70 days old; (2) starting from 110 days old, young vocalizations are mostly uniformly distributed over the whole night and start shortly after sunset; (3) age-classes of 110,130 and 150 days showed a quite generalized cyclical pattern of vocal activity through the night.

The vocal activity of the young represents a useful method for detecting occupied nests (Penteriani et al. 2000, Marchesi et al. 2002). On the basis of the recorded call rates, censusing successful Eagle Owl territories by passive auditory surveys of young begging should start when the young are at least 110 days old, when call activity increases and becomes evenly distributed over the whole night. Before this stage, passive auditory surveys should be planned only close to sunset and sunrise.

Because Eagle Owl begging is also frequently performed during the day, concerns were expressed at the fact that this call was used for adult feeding alone (Penteriani et al. 2000). In the current work, we have shown that many calls were performed by the young when the adults were either not calling or absent. The patterns of vocal behaviour reported in the present study could give further support to the hypothesis that young begging calls could also represent a way of communicating within family groups (i.e. contact calls). In fact, increasing frequencies of this call coincided with the period when the young moved several hundred metres from the nest and when the mean distances between siblings increased. In agreement with the idea of a multiple function of owl begging, Roulin et al. (2000) showed that Barn Owl food begging is not only directed at parents: when performed in their absence, it represents a sibling's source of information about the willingness of its siblings to contest the next delivered prey item (the sibling negotiation hypothesis). 


\section{Movements during the PFDP}

To our knowledge, our radiotagged, young Eagle Owls showed the longest PFDP and furthest distances from the nest ever recorded for an owl species. In comparison, the young of some other owl species spend relatively little time at the natal site before dispersing. Age at dispersal previously reported for owl species ranges from 45 to 100 days (Belthoff \& Ritchison 1989, Miller 1989, Ellsworth \& Belthoff 1997, Ganey et al. 1998, King \& Belthoff 2001, Todd 2001, Forsman et al. 2002). Concerning the movements of the young of other owl species during PFDP, movements around nests are usually more reduced than for our Eagle Owls: $38-280 \mathrm{~m}$ for Burrowing Owls Speotyto cunicularia (King \& Belthoff 2001) and 500-800 m for Eastern Screech Owls Otus asio (Belthoff \& Ritchison 1989).

In general, although some information is available on the sizes of owl home ranges and areas of concentrated 19 12 use within tergitories, 1 lititle or no information

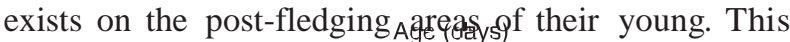
is peculiar given: (1) the recognized importance of squch areas for diurnal raptors (i.e. the ecological counterparts of the Strigiformes) (e.g. Kenward et al. 1993, Kennedy et al. 1994) and (2) the frequently reported high mortality rates of young prior to dispersal (e.g. 18.2\% for Eastern Screech Owls, Belthoff \& Ritchison 1989; 91.7 and 36.4\% for Tawny Owls Strix aluco, Petty \& Thirgood 1989 and Coles \& Petty 1997, respectively; and $16.1 \%$ for Mexican Spotted Owls Strix occidentalis lucida, Willey \& Van Riper 2000). Such characteristics are likely to be more extreme in human-altered landscapes, where, for example, current evidence seems to indicate that predispersal mortality could markedly affect Eagle Owl offsprings, reducing the actual breeding success of nesting territories (Sergio et al. 2004). Such a mortality risk is probably increased by the large amount of time (c. 150 days) that young Eagle Owls spend in the post-fledging area. Such long exposure to potential mortality factors exaggerates the importance, for conservation management, of identifying and taking into account potential mortality factors acting within the post-fledging areas, especially for those species that move largely around their nest before dispersal.

Finally, occasional exploratory movements during the PFDP, also reported for Great Horned Owls (Dunstan 1970), should be taken into account when censusing occupied nests or evaluating breeding success by passive auditory surveys of young
Eagle Owls. In fact, the best stages for listening to begging calls also coincide with the time of furthest movements from the nest, increasing the possibility of bias in nest checking and productivity evaluation. Because during post-fledging the young may perch far from their nest for more than 1 day, several listening sessions should be planned on different days before considering a territory as unoccupied or unsuccessful. Moreover, because at this stage siblings usually moved together and stayed in close proximity during the whole night, as also described for Mexican Spotted Owls (Arsenault et al. 1997), it may be possible to hear no calls at all for a full night even in close proximity to the original nest.

For their help with logistics and fieldwork we are particularly grateful to J. Ayala, J. Balbontín, E. Casado, M. De La Riva, R. Díaz, M. Ferrer, F. González, Huerto de los Arroyos, E. Luque, M. Méndez, P. Montero, F. Moreno, J.F. Navarro, L. Ornero, G. Penteriani, E. Revilla, F. Rodríguez and E. Fernández, together with the landowners who gave permission for work on their property. The first draft of this manuscript was greatly improved by the critical reviews of A. Aebischer, M. Ferrer, A.G. Gosler, M. Licantropi, S. Redpath and an anonymous referee. Funding for this study was provided by LICOR43 of Diego Zamora S.A. (http://www.buho-ebd.com/) and EMASESA. We marked owlets under Junta de Andalucía - Consejería de Medio Ambiente permit Nos. SCFFS-AFR/GGG RS-260/02 and SCFFS-AFR/CMM RS-1904/02.

\section{REFERENCES}

Amar, A., Arroyo, B.E. \& Bretagnolle, V. 2000. Post-fledging dependence and dispersal in hacked and wild Montagu's Harriers Circus pygargus. Ibis 142: 21-28.

Arsenault, D.P., Hodgson, A. \& Stacey, P.B. 1997. Dispersal movements of juvenile Mexican Spotted Owls (Strix occidentalis lucida) in New Mexico. In Duncan, J.R., Johnson, D.H. \& Nicholls, T.H. (eds) Biology and Conservation of Owls of the Northern Hemisphere: 47-57. St. Paul: USDA Forest Service. General Technique Report NC-190.

Belthoff, J.R. \& Ritchison, G. 1989. Natal dispersal of Eastern Screech-owls. Condor 91: 254-265.

Boal, C.W. 1994. A photographic and behavioural guide to aging nestling Northern Goshawks. Stud. Avian Biol. 16: 32-40.

Bustamante, J. \& Hiraldo, F. 1989. Post-fledging dependence period and maturation of flight skills in the Black Kite Milvus migrans. Bird Study 36: 199-204.

Bustamante, J. \& Negro, J.J. 1994. The post-fledging dependence period of the Lesser Kestrel (Falco naumanni) in southwestern Spain. J. Raptor Res. 28: 158-163.

Clark, W.S. 2000. A Field Guide to the Raptors of Europe, the Middle East, and North Africa. Oxford: Oxford University Press.

Coles, C.F. \& Petty, S.J. 1997. Dispersal behaviour and survival 
of juvenile Tawny Owls (Strix aluco) during the low point in a vole cycle. In Duncan, J.R., Johnson, D.H. \& Nicholls, T.H. (eds) Biology and Conservation of Owls of the Northern Hemisphere: 111-118. St. Paul: USDA Forest Service. General Technique Report NC-190.

Delgado, M.M. \& Penteriani, V. in press. Sexing Eagle Owls (Bubo bubo) by morphology. J. Raptor Res. in press.

Dunstan, T.C. 1970. Post-fledging activities of juvenile Great Horned Owls as determined by radio-telemetry. PhD dissertation, University of South Dakota.

Ellsworth, E. \& Belthoff, J.R. 1997. Sex-biased dispersal of young Western Screech-Owls (Otus kennicottii) in southwestern Idaho. In Duncan, J.R., Johnson, D.H. \& Nicholls, T.H. (eds) Biology and Conservation of Owls of the Northern Hemisphere: 155-159. St. Paul: USDA Forest Service. General Technique Report NC-190.

Forsman, D. 1999. The Raptors of Europe and the Middle East. A Handbook of Field Identification. London: T. \& A.D. Poyser.

Forsman, D.E., Anthony, R.G., Reid, J.A., Loschl, P.J., Sovern, S.G., Taylor, M., Biswell, B.L., Ellingson, A., Meslow, E.C., Miller, G.S., Swindle, K.A., Thrailkill, J.A., Wagner, F.F. \& Seaman, D.E. 2002. Natal and breeding dispersal of northern Spotted Owls. Wildl. Monogr. 149: 1-35.

Fyfe, R.W. \& Olendorff, R.R. 1976. Minimizing the Dangers of Nesting Studies to Raptors and Other Sensitive Species. Canadian Wildlife Service, Occasional Paper no. 23.

Ganey, J.L., Block, W.M., Dwyer, J.K., Strohmeyer, B.E. \& Jenness, J.S. 1998. Dispersal movements and survival rates of juvenile Mexican Spotted Owls in northern Arizona. Wilson Bull. 110: 206-217.

Hamel, P.B. 1974. Age and sex determination of nestling Common Grackles. Bird Banding 45: 16-23.

Hartley, R.R. \& Mundy, P.J. 2003. Morphometrics and status of Ayres's Hawk-Eagle in Zimbabwe. J. Raptor Res. 37: 4454.

Henny, C.J. 1972. An Analysis of the Population Dynamics of Selected Avian Species: 1-99. Wildlife Research Report 1. Washington, DC: US Fish \& Wildlife Service.

Hill, G.E. 1987. Aging and sexing black-headed grosbeaks in alternate plumage. J. Field Ornithol. 58: 311-317.

Hoffmeister, D.F. \& Seltzer, H.W. 1947. The postnatal development of two broods of Great Horned Owls (Bubo virginianus). Univ. Kansas. Publ. Museum Natural History 1: 157-173.

Holcomb, L.C. \& Twiest, G. 1971. Growth and calculation of age for Red-winged Blackbird nestlings. Bird Banding 42: 1-17.

Howell, T.R. 1964. Notes on incubation and nestling temperature and behavior of captive owls. Wilson Bull. 76: 28-36.

Josephson, B. 1980. Aging and sexing Snowy Owls. J. Field Ornithol. 51: 149-160.

Keedwell, R.J. 2003. Does fledging equal success? Post-fledging mortality in the Black-fronted Tern. J. Field Ornithol. 74: 217-221.

Kennedy, P.L., Ward, J.M., Rinker, G.A. \& Gessaman, J.A. 1994. Post-fledging areas in Northern Goshawk home ranges. Stud. Avian Biol. 16: 75-82.

Kenward, R.E., Marcström, V. \& Karlbom, M. 1993. Postnestling behaviour in Goshawks, Accipiter gentilis: the causes of dispersal. Anim. Behav. 46: 365-370.

King, R.A. \& Belthoff, J.R. 2001. Post-fledging dispersal of Burrowing Owls in southwestern Idaho: characterization of movements and use of satellite burrows. Condor 103: 118126.
Lack, D. 1954. The Natural Regulation of Animal Numbers. Oxford: Clarendon Press.

Lack, D. 1968. Ecological Adaptations for Breeding in Birds. London: Methuen.

Marchesi, L., Sergio, F. \& Pedrini, P. 2002. Costs and benefits of breeding in human-altered landscapes for the Eagle Owl Bubo bubo. Ibis 144: 164-177.

Marquiss, M. \& Newton, I. 1981. A radio-tracking study of the ranging behaviour and dispersion of European sparrowhawk Accipiter nisus. J. Anim. Ecol. 51: 111-133.

Martínez, J.A., Zuberogoitia, I. \& Alonso, R. 2002. Rapaces Nocturnas. Guía Para la Determinación de la Edad Y El Sexo En Las Estrigiformes Ibéricas. Madrid: Monticola Ediciones.

McCollough, M.A. 1989. Molting sequence and aging of Bald Eagles. Wilson Bull. 101: 1-10.

Mikkola, H. 1983. Owls of Europe. Berkhamsted: T. \& A.D. Poyser.

Miller, G.S. 1989. Dispersal of juvenile northern Spotted Owls in Oregon. PhD dissertation, Oregon State University.

Moritsch, M.Q. 1983a. Photographic Guide for Aging Nestling Prairie Falcons. Boise: USDI Bureau Land Management.

Moritsch, M.Q. 1983b. Photographic Guide for Aging Nestling Red-Tailed Hawks. Boise: USDI Bureau Land Management.

Moritsch, M.Q. 1985. Photographic Guide for Aging Nestling Ferruginous Hawks. Boise: USDI Bureau Land Management.

Morton, E.S. 1973. On the evolutionary advantages and disadvantages of fruit eating in tropical birds. Am. Nat. 107: 8-22.

Moss, D. 1979. Growth of nestling Sparrowhawks (Accipiter nisus). J. Zool., Lond. 187: 297-314.

Murphy, M.T. 1981. Growth and aging of nestling Eastern Kingbirds and Eastern Phoebes. J. Field Ornithol. 52: 309_ 316.

O'Connor, R.J. 1975. The influence of brood size upon metabolic rate and body temperature in nestling Blue Tits Parus caeruleus and House Sparrows Passer domesticus. J. Zool., Lond. 175: 391-403.

Penteriani, V. 1996. The Eagle Owl. Bologna: Calderini Edagricole (in Italian).

Penteriani, V. 2001. The annual and diel cycles of Goshawk vocalisations at nest sites. J. Raptor Res. 35: 24-30.

Penteriani, V. 2002. Variation in the function of Eagle Owl vocal behaviour: territorial defence and intra-pair communication? Ethol. Ecol. Evol. 14: 275-281.

Penteriani, V. 2003. Breeding density affects the honesty of bird vocal displays as possible indicators of male/territory quality. Ibis 145: E127-E135.

Penteriani, V., Gallardo, M. \& Cazassus, H. 2000. Diurnal vocal activity of young Eagle Owls and its implications in detecting occupied nests. J. Raptor Res. 34: 232-235.

Penteriani, V., Gallardo, M. \& Roche, P. 2002. Landscape structure and food supply affect Eagle Owl (Bubo bubo) density and breeding performance: a case of intra-population heterogeneity. J. Zool., Lond. 257: 365-372.

Petty, S.J. \& Thirgood, S.J. 1989. A radio tracking study of postfledging mortality and movements of Tawny Owls in Argyll. Ring. Migr. 10: 75-82.

Pickwell, G. 1948. Barn Owl growth and behaviorisms. Auk 65: 359-373.

Ricklefs, R.E. 1967. A graphical method of fitting equations to growth curves. Ecology 48: 978-983. 
Ricklefs, R.E. 1968. Patterns of growth in birds. Ibis 110: 419-451.

Ricklefs, R.E. 1969. Preliminary models for growth rates of altricial birds. Ecology 50: 1031-1039.

Ricklefs, R.E. 1973. Patterns of growth in birds. II. Growth rate and mode of development. Ibis 115: 177-201.

Roulin, A., Kölliker, M. \& Richner, H. 2000. Barn Owl (Tyto alba) siblings vocally negotiate resources. Proc. R. Soc. Lond. B 267: 459-463.

Sergio, F. 2003. Relationship between laying dates of Black Kites Milvus migrans and spring temperature in Italy: rapid response to climate change? J. Avian Biol. 34: 144-149.

Sergio, F. \& Bogliani, G. 1999. Eurasian Hobby density, nest area occupancy, diet and productivity in relation to intensive agriculture. Condor 101: 806-817.

Sergio, F., Marchesi, L., Pedrini, P., Ferrer, M. \& Penteriani, V. 2004. Electrocution alters the distribution and density of a top predator, the eagle owl Bubo bubo. J. Appl. Ecol. 41: 836-845.

Steenhof, K. 1987. Assessing raptor reproductive success and productivity. In Giron Pendleton, B.A., Millsap, B.A., Kline, K.W. \& Bird, D.M. (eds) Raptor Management Techniques Manual: 157-170. National Wildlife Federal Service Technical Series no. 10.

Sullivan, K.A. 1989. Predation and starvation: age specific mortality in juvenile juncos (Junco phaeonotus). J. Anim. Ecol. 58: $275-286$.
Sumner, E.L. Jr 1928. Notes on the development of young Screech Owls. Condor 30: 333-338.

Sumner, E.L. Jr 1929. Comparative studies on the growth of young raptors. Condor 31: 85-111.

Todd, L.D. 2001. Dispersal patterns and post-fledging mortality of juvenile Burrowing Owls in Saskatchewan. J. Raptor Res. 35: 282-287.

Warkentin, I.G., James, P.C. \& Oliphant, L.W. 1992. Use of a plumage criterion for aging female Merlins. J. Field Ornithol. 63: $473-475$.

Watson, A. 1957. The behaviour, breeding, and food-ecology of the Snowy Owl Nyctea scandiaca. Ibis 99: 419-462.

Weathers, W.W. \& Sullivan, K.A. 1989. Juvenile foraging proficiency, parental effort, and avian reproductive success. Ecol. Monogr. 59: 223-246.

Willey, D.W. \& Van Riper, C. III. 2000. First-year movements by juvenile Mexican Spotted Owls in the canyonlands of Utah. J. Raptor Res. 34: 1-7.

Young, L.S. \& Kochert, M.N. 1987. Marking techniques. In Giron Pendleton, B.A., Millsap, B.A., Kline, K.W. \& Bird, D.M. (eds) Raptor Management Techniques Manual: 125-156. National Wildlife Federal Service, Technical Series no. 10. 